FIGUEIREDO AST; RESENDE JTV; FARIA MV; PAULA JT; RIZZARDI DA; MEERT L. 2016. Agronomic evaluation and combining ability of tomato inbred lines selected for the industrial segment. Horticultura Brasileira 34: 086-092. DOI - http://dx.doi.org/10.1590/S0102-053620160000100013

\title{
Agronomic evaluation and combining ability of tomato inbred lines selected for the industrial segment
}

\author{
Alex ST Figueiredo ${ }^{1}$; Juliano TV Resende²; Marcos V Faria²; Juliana T Paula²; Diego A Rizzardi \\ Leandro Meert $^{2}$ \\ ${ }^{1}$ Sakata Seeds Sudamerica, Bragança Paulista-SP, Brasil; alex.figueiredo@sakata.com.br; ${ }^{2}$ Universidade Estadual do Centro Oeste \\ (UNICENTRO), Guarapuava-PR, Brasil; jvresende@uol.com.br; mfaria@unicentro.br; jtaufferp@gmail.com; meert2012@hotmail.com; \\ ${ }^{3}$ Universidade Estadual de Maringá (UEM), Maringá-PR, Brasil; diegoragro@hotmail.com
}

\begin{abstract}
This study carried out agronomic evaluation and estimated the combining ability of tomato lines for the industrial segment, aiming to elect promising genotypes for breeding and to find simple hybrids with superior traits. Randomized-blocks design was used with 57 treatments (45 experimental hybrids, 10 lines and 2 checks treatments) with 3 replications. A complete diallel among 10 tomato lines for processing was used. Evaluated traits were: fruit total (YT) and commercial production (YC), pulp yield (YP), fruit average mass (MM) and total soluble solids content (TSS). Diallel crosses allowed synthesizing experimental hybrids with superior traits when compared to commercial hybrids. Non-additive effects prevailed over the expression of YT, YC, YP and TSS, whereas additive effects prevailed for MM. Lines RVT-08, RVT-05 and RVT-10 are most appropriate for intrapopulational breeding. Experimental hybrids RVT-08 x RVT-09, RVT-07 x RVT-10 and RVT-08 x RVT-10 were pointed as the experimental genotypes with the best performance, surpassing the commercial genotypes for the traits evaluated.
\end{abstract}

Keywords: Solanum lycopersicum, diallel analysis, industrial processing.

\section{RESUMO}

Capacidade combinatória de linhagens de tomateiro de crescimento determinado para processamento industrial

O presente trabalho teve como objetivo avaliar o desempenho agronômico e estimar a capacidade combinatória de linhagens de tomateiro industrial visando eleger genótipos promissores para o melhoramento e encontrar híbridos simples superiores. O delineamento utilizado foi blocos casualizados com 57 tratamentos (45 híbridos experimentais, 10 linhagens e 2 testemunhas), em três repetições. Utilizou-se um dialelo completo entre 10 linhagens de tomateiro industrial. Foram avaliados a produtividade total (PT) e comercial (PC) de frutos, rendimento de polpa (RP), massa média dos frutos (MM) e teor total de sólidos solúveis (TSS). Os cruzamentos dialélicos propiciaram a formação de híbridos experimentais superiores aos híbridos comerciais. Os efeitos não aditivos predominaram sobre a expressão das características PT, PC, RP e TSS enquanto que para a MM houve a predominância de efeitos aditivos. As linhagens RVT-08, RVT-05 e RVT-10 são as mais apropriadas para o melhoramento intrapopulacional. Os híbridos experimentais RVT-08 x RVT-09, RVT-07 x RVT-10 e RVT-08 x RVT-10 se destacaram como os genótipos experimentais de melhor desempenho do experimento, superando as testemunhas comerciais para as características avaliadas.

Palavras chave: Solanum lycopersicum, análise dialélica, processamento industrial.

(Recebido para publicação em 16 de maio de 2014; aceito em 9 de setembro de 2015)

(Received on May 16, 2014; accepted on September 9, 2015)

$\mathrm{T}$ omato (Solanum lycopersicum) is the second most important vegetable crop in Brazil and worldwide, grown in nearly all over the Brazilian territory. This fact is due to social and economic importance of the crop, as well as its nutraceutical benefits (Gameiro et al., 2007).

Tomato fruits can be intended both for fresh consumption and for industrial processing, producing valueadded derivatives. Industrial tomato production has held a prominent position in Brazilian agribusiness. In 2011, Brazil produced 1.81 million tons of tomatoes for the industrial segment, achieving the fifth position in the ranking of the world's largest producers (Boiteux et al., 2012).

The use of hybrids is the main reason, which led Brazil to reach this position (Aragão et al., 2004; Boiteux et al., 2012). Generally, hybrids are more productive than lines and openpollinated populations, due to a more effective exploitation of genetic effects (Maluf, 2001). Thus, the use of hybrids in tomato crop is reasonable considering the several advantages provided to producers and consumers, mainly: higher productivity, earliness, quality of fruits and possibility to match resistance to pests and diseases in the same genotype (Aragão et al., 2004; Santos et al., 2011; Schwarz et al., 2013).

Tomato is an autogamous species and its genetic base became narrow along the process of domestication, preventing intrapopulational breeding strategies to provide satisfactory genetic gains in crop breeding (Amaral Júnior et al., 1997, 1999; Souza et al., 2012). 
In this sense, the recombination of the genetic variability is an excellent alternative for obtaining plants with superior genetic merit (Maciel et al., 2010; Souza et al., 2012).

One of the most used methodologies in breeding programs, including for tomato, are diallel crosses (Maluf, 2001). Diallels are a type of genetic design which provides the breeder information on genetic parameters such as prevailing gene action, combination aptitude of parents, heterosis as well as the best breeding strategies to be adopted (Cruz et al., 2012; Souza et al., 2012). The authors found several studies on the use of diallel crosses in tomato, for various characteristics such as fruit productivity (Amaral Júnior et al., 1997, 1999; Souza et al., 2012), pest resistance (Maciel et al., 2010) and disease resistance (Elsayed et al., 2012), post-harvest (Resende et al., 2000; Akhtar \& Hazra, 2013).

Most research works with industrial tomato breeding in Brazil are linked to public education and research institutions, which do not have enough financial resources to launch cultivars regularly. However, most of the commercial hybrids of tomato available to Brazilian producers are obtained from other countries where this fruit is grown. These hybrids are introduced into an experimental network and the most adapted and stable ones end up being registered and sold in the domestic seed market (Aragão et al., 2004). Thus, more studies in order to obtain germplasm adapted to Brazilian growing conditions and which produces high quality raw material for the fruit processing agribusiness, are necessary. The goal of this work was to estimate combining ability of industrial tomato lines, aiming to elect potential genotypes for breeding programs and find superior simple hybrids of tomato intended to industrial segment.

\section{MATERIAL AND METHODS}

The experiment was carried out in the experimental field of the "Núcleo de Pesquisa em Hortaliças (Research Center for Vegetable Crops) of the
Universidade Estadual do Centro-Oeste (UNICENTRO) (State University of the Central-Western Paraná), in Guarapuava, Paraná State, Brazil. The soil in the experimental field is classified as Distrofic Brown Oxisol and the local climate is characterized as subtropical and humid $(\mathrm{Cfb})$ without definite dry season and mild hot summers and harsh winters, according to Köppen classification.

The experiment consisted of a complete diallel among 10 lines of industrial tomato selected by UNICENTRO. In total, 57 genotypes of tomato with industrial aptitude (45 single hybrids of the diallel, 10 lines and 2 checks) were evaluated. Randomized blocks were used, with three replications. The description of lines and checks is presented in Table 1. Each experimental unit consisted of two contiguous plant rows, with eight plants in each one, grown at $1.20 \mathrm{~m}$ between lines and 0.35 between plants. Two plants of each end of the plot were used as border lines, totaling an area of $5.46 \mathrm{~m}^{2}$.

Genotypes were sown in trays of 200 cells following seedling transplanting to the field ( \pm 30 days). During the crop cycle, three fertilization operations were carried out (at planting, at flowering and at full fructification) based on soil chemical analysis and on nutritional requirements of the crop. The irrigation system used was sprinkler, operated according to the necessity of the plants. Pest and disease control was carried out through insecticide (acephate, triflumuron and thiamethoxam) and fungicides applications (copper oxychloride, metalaxyl-M, mancozeb and chlorothalonil), weekly, using recommended doses for the crop.

After 85 DAT of seedlings, four harvests were carried out, in which weight and total number of harvested fruits in each plot was calculated. The fruits were classified as marketable (regular/small defects) and unmarketable fruits (serious defects) according to the standards of the Ministério da Agricultura (Ministry of Agriculture), Decree 553/1995 (BRASIL, 1995). Afterwards, total (YT) and commercial yield (YC) of the fruits $(\mathrm{kg} / \mathrm{ha})$ and average mass of fruits (MM) were calculated. In the third harvest, eight fruits of each plot were collected in order to verify the soluble solids content (TSS). These fruits were sanitized and then homogenized. Afterwards, total soluble solids content ( $\mathrm{SS},{ }^{\circ} \mathrm{Brix}$ ) was measured, using a bench digital refractometer (model PAL-1).

Pulp yield (YP) of the genotypes was calculated according to Giordano et al. (2000), using the expression $\mathrm{YP}=$ $\left[\left(\mathrm{YT}^{*} 0.95\right) * \mathrm{TSS}\right] / 28$, in which YP is the total yield of the fruits $(\mathrm{t} / \mathrm{ha})$ and TSS is the soluble solids content ( $\left.{ }^{\circ} \mathrm{Brix}\right)$. The authors considered pulp concentration at $28^{\circ} \mathrm{Brix}$ as reference for calculation.

After verifying homogeneity and normality of errors through Bartllet and Lilliefors test $(p<0.05)$ respectively, the authors proceeded to the analysis of variance for randomized blocks, with the unfolding of the degree of freedom of treatment into effects of lines, experimental hybrids, commercial hybrids and contrasts of means between "lines vs hybrids" and "experimental hybrids vs commercial hybrids" (Cruz et al., 2012). After analysis of variance, the means of treatments were grouped through the Scott Knott test $(\mathrm{p}<0.05)$.

For diallel analysis, the sum of squares of treatments were unfolded into estimates of general (GCA) and specific aptitude for combination (SCA), according to the Method II (parents and $\mathrm{F}_{1}$ hybrids), Model 1 (fixed effect for genotype), according to Griffing (1956). The mathematic model adopted follows $\mathrm{Y}_{\mathrm{ij}}=\mathrm{m}+\mathrm{g}_{\mathrm{i}}+\mathrm{g}_{\mathrm{j}}+\mathrm{s}_{\mathrm{ij}}+\mathrm{e}_{\mathrm{ij}}$ in which $\mathrm{Y}_{\mathrm{ij}}=$ value of hybrid combination $(\mathrm{i} \neq \mathrm{j}) ; \mathrm{m}=$ general average; $g_{i}$ and $g_{j}=$ estimates of general aptitude for combination of the parents $i^{\text {th }}$ and $j^{\text {th }}$, respectively; $\mathrm{s}_{\mathrm{ij}}=$ estimates of specific aptitude for combination of the parents $\mathrm{i}$ and $\mathrm{j}$ and $\mathrm{e}_{\mathrm{ij}}=$ average experimental error. The genetic analyses were carried out using statistical software Genes (Cruz, 2013).

\section{RESULTS AND DISCUSSION}

Results of the analysis of variance and of the diallel are reported in Table 2. Commercial hybrids and lines did not show significant effects on 
Table 1. Agronomic and morphological characteristics of genitor lines and commercial hybrids (características agronômicas e morfológicas das linhagens genitoras e híbridos comerciais utilizados no experimento). Guarapuava, UNICENTRO, 2012.

\begin{tabular}{lccccccc}
\hline Genotype & $\begin{array}{c}\text { Crop cycle } \\
\text { (days) }\end{array}$ & $\begin{array}{c}\text { Leaf index } \\
\mathbf{( \% )}\end{array}$ & $\begin{array}{c}\text { Fruit flesh } \\
(\mathbf{m m})\end{array}$ & $\begin{array}{c}\text { Fruit for- } \\
\text { mat }\end{array}$ & $\begin{array}{c}\text { Fruit } \\
\text { color }\end{array}$ & $\begin{array}{c}\text { Growth } \\
\text { habit }\end{array}$ & JT \\
\hline RVT-01 & 122 & 95 & 8.47 & $\mathrm{Al}$ & $\mathrm{Ama}$ & Det & $\mathrm{x}$ \\
RVT-02 & 120 & 53 & 7.29 & $\mathrm{Al}$ & $\mathrm{Cl}$ & Det & $\mathrm{x}$ \\
RVT-03 & 124 & 71 & 8.53 & $\mathrm{Al}$ & $\mathrm{Cl}$ & Det & $\mathrm{x}$ \\
RVT-04 & 120 & 57 & 9.99 & $\mathrm{Al}$ & $\mathrm{Int}$ & $\mathrm{Det}$ & $\mathrm{x}$ \\
RVT-05 & 121 & 55 & 7.34 & $\mathrm{Al}$ & $\mathrm{Cl}$ & Det & $\mathrm{x}$ \\
RVT-06 & 121 & 66 & 8.83 & $\mathrm{Al}$ & $\mathrm{Int}$ & Det & $\mathrm{x}$ \\
RVT-07 & 119 & 34 & 8.97 & $\mathrm{Al}$ & $\mathrm{Cl}$ & Det & $\mathrm{x}$ \\
RVT-08 & 121 & 60 & 7.97 & $\mathrm{Al}$ & $\mathrm{Cl}$ & Det & $\mathrm{x}$ \\
RVT-09 & 123 & 82 & 6.61 & $\mathrm{Red}$ & $\mathrm{Int}$ & Det & $\mathrm{x}$ \\
RVT-10 & 121 & 43 & 8.22 & $\mathrm{Al}$ & $\mathrm{Int}$ & Det & $\mathrm{x}$ \\
\hline AP-529 & 120 & 53 & 4.99 & Per & $\mathrm{Cl}$ & Det & $\mathrm{x}$ \\
Tinto & 120 & 67 & 4.51 & $\mathrm{Al}$ & $\mathrm{Int}$ & Det & $\mathrm{x}$ \\
\hline
\end{tabular}

Al: long fruit (fruto alongado); Red: round fruit (fruto redondo); Per: pyriform fruit (fruto periforme); Amr: yellow fruit (fruto amarelo); Cl: bright fruit (fruto claro); Int: Intense red fruit (fruto vermelho intenso); Det: determined (determinado); JT: jointless ; X= Presence of jointless.

YC whereas experimental hybrids influenced significantly $(\mathrm{p}<0.05)$ all variables studied in the experiment (Table 2). These results prove that diallel crosses among lines allowed the generation of genetic variability, being possible to select the best tomato hybrids for processing. Although the genetic basis of tomato crop is narrow, due to inbreeding and domestication during evolution (Amaral Júnior et al., 1999) obtaining variability by recombining genotypes is possible, enabling to obtain high-performance hybrids (Aragão et al., 2004; Santos et al., 2011, Andrade et al., 2014).

Contrast among the means of "lines $v s$ other genotypes" presented negative and significant estimates $(\mathrm{p}<0,05)$ for variables $\mathrm{YT}, \mathrm{YC}, \mathrm{YP}$ and $\mathrm{MM}$, demonstrating the superiority of experimental hybrids over their parental lines (Table 2). Only TSS presented positive and significant contrast estimates, showing that on average, the lines showed higher TSS compared to other genotypes studied (Table 2).

Contrast among experimental hybrids $v s$ commercial hybrids showed positive and significant estimates $(\mathrm{p}<0.05)$ for YT, YC, YP and TSS demonstrating the average superiority of experimental hybrids over the means of their parental lines (Table 2). These results are of great importance and enable studies which allow the recombination of existing germplasm aiming to find superior hybrids which maximize genetic effects such as heterosis. Other studies confirm the possibility of obtaining promising experimental genotypes of tomato for industrial segment (Aragão et al., 2004) and fresh consumption (Maciel et al., 2010) by recombination of elite genotypes.

For MM, the contrast among experimental hybrids vs commercial hybrids presented negative and significant estimates $(\mathrm{p}<0.05)$, showing the inferiority of experimental hybrids compared to commercial hybrids for MM (Table 2). This statement is proven by the performance of hybrid Tinto, which presented the highest MM of the experiment (104.40 g/fruit) not being grouped with any other genotype. Schwarz et al. (2013) also proved the superiority of this hybrid with respect to $\mathrm{MM}$, this being considered one of the genotypes with the highest MM in their study.

General combining ability (GCA) is a consequence of the behavior of a given parent for crosses in which it took part in, reflecting the effect of additive genes (Griffing, 1956). High and absolute values of GCA are present in genotypes whose favorable allele frequency is higher or lower than the average frequency of favorable alleles at all other parents of the diallel (Cruz et al., 2012). Specific combining ability (SCA) is the deviation of a hybrid in relation to the expected based on GCA of their parents, reflecting the nonadditive gene action (Cruz et al., 2012).

In relation to the diallel, mean square of GCA and SCA were significant for all traits showing that both additive and non-additive genes are important on genetic control of these traits. Pádua et al. (2010) used tomato lines from different genetic backgrounds and observed significant estimates of GCA and SCA for fruit production, and attributed these results to genetic divergence between the parents. Results similar to this study can be found in other studies (Souza et al., 2012; Saleem et al., 2013).

Relationship between quadratic components of GCA and SCA indicates which genetic effect is predominant in the character expression (Cruz et al., 2012). When GCA is higher than SCA, additive-effect genes are predominant in the character expression, so intrapopulational breeding strategies are the best option. However, when SCA is higher than GCA, non-additive genes are predominant and interpopulational breeding strategies, which explore the effects of dominance, overdominance and epistasis are most appropriate. 
Table 2. Summary of ANOVA (experiment and diallel) with estimates of mean square for the characteristics evaluated in 57 genotypes of tomato for industrial segment (resumo da ANOVA do experimento e do dialelo, com as estimativas de quadrado médio para as características avaliadas em 57 genótipos de tomateiro industrial). Guarapuava, UNICENTRO, 2012.

\begin{tabular}{|c|c|c|c|c|c|c|}
\hline \multirow{2}{*}{ Variation source } & \multirow{2}{*}{ DF } & \multicolumn{5}{|c|}{ MS } \\
\hline & & YT & $\mathrm{YC}$ & $\mathbf{Y P}$ & MM & TSS \\
\hline Treatment & $(56)$ & $321,016,802^{*}$ & $247,197,032^{*}$ & $8,589,666^{*}$ & $320.40^{*}$ & $0.3511^{*}$ \\
\hline Experimental hybrids (HE) & 44 & $228,197,609^{*}$ & $167,524,509^{*}$ & $7,622,908^{*}$ & $227.61^{*}$ & $0.3419^{*}$ \\
\hline Inbred lines (Lin) & 9 & $197,896,613^{*}$ & $165,011,778^{*}$ & $3,858,102^{*}$ & $336.48^{*}$ & $0.3175^{*}$ \\
\hline Commercial hybrids (HC) & 1 & $172,772,843^{*}$ & $86,499,153^{\mathrm{NS}}$ & $2,817,377^{*}$ & $3479.56^{*}$ & $0.6016^{*}$ \\
\hline Lin $v s \mathrm{HE}+\mathrm{HC}$ & 1 & $\begin{array}{c}5,358,084,808.8^{*} \\
(-14,717,45)^{* * *}\end{array}$ & $\begin{array}{c}4,242,193,718^{*} \\
(-13,095.53)\end{array}$ & $\begin{array}{l}92,008,972^{*} \\
(-1,928.60)\end{array}$ & $\begin{array}{l}280.61^{*} \\
(-3.36)\end{array}$ & $\begin{array}{c}0.4294^{*} \\
(0.1317)\end{array}$ \\
\hline $\mathrm{HE} v s \mathrm{HC}$ & 1 & $\begin{array}{c}451,601,217^{*} \\
(8,866.34) \\
\end{array}$ & $\begin{array}{c}658,108,797^{*} \\
(10,703.25) \\
\end{array}$ & $\begin{array}{c}16,059,453^{*} \\
(1,671.98) \\
\end{array}$ & $\begin{array}{c}1,147.50^{*} \\
(-14.13)\end{array}$ & $\begin{array}{c}0.7269^{*} \\
(0.3537) \\
\end{array}$ \\
\hline Block & 2 & $17,990,557$ & $16,672,591$ & $235,665.15$ & 374.80 & 0.0478 \\
\hline Error & 112 & $22,951,369$ & $23,290,157$ & 498,498 & 40.25 & 0.0098 \\
\hline Total & 170 & - & - & - & - & - \\
\hline Mean & - & 57.86 & 52.06 & 8.12 & 66.21 & 4.14 \\
\hline $\mathrm{CV}(\%)$ & - & 8.28 & 9.27 & 8.69 & 9.58 & 2.39 \\
\hline \multicolumn{7}{|l|}{ Diallel ANOVA } \\
\hline Treatment & $(54)$ & $322,489,380^{*}$ & $247,471,773^{*}$ & $8,752,080^{*}$ & $244.9^{*}$ & $0.3381^{*}$ \\
\hline $\operatorname{GCA}\left(\hat{g}_{\mathrm{i}}\right)$ & 9 & $328,025,332^{*}$ & $226,750,329^{*}$ & $11,477,603^{*}$ & $1.081^{*}$ & 0.4671 \\
\hline $\operatorname{SCA}\left(\hat{\mathrm{s}}_{\mathrm{ij}}\right)$ & 45 & $321,382,189^{*}$ & $251,616,062^{*}$ & $8,206,975^{*}$ & $77.6^{*}$ & 0.3123 \\
\hline Error & 108 & $23,349,135$ & $23,723,696$ & 508,580 & 37.15 & 0.0101 \\
\hline Mean & - & 58.08 & 52.35 & 8.15 & 6.70 & 4.16 \\
\hline $\mathrm{CV}(\%)$ & - & 8.31 & 9.30 & 8.74 & 9.27 & 2.42 \\
\hline \multicolumn{7}{|l|}{ Quadratic components } \\
\hline $\operatorname{GCA}\left(\hat{g}_{\mathrm{i}}\right)$ & - & $8,463,227$ & $5,639,628$ & 304,695 & 29.00 & 0.00012 \\
\hline $\operatorname{SCA}\left(\hat{\mathrm{s}}_{\mathrm{ij}}\right)$ & - & $99,344,351$ & $75,964,121$ & 566,131 & 13.49 & 0.00147 \\
\hline
\end{tabular}

*Significant by $\mathrm{F}$ test $(\mathrm{p}<0.05)$ \{significativo pelo teste de $\mathrm{F}(\mathrm{p}<0,05)\} ; * *$ Estimates of contrasts (Estimativas de contrastes).

For variables YT, YC, YP and TSS the quadratic component of SCA was higher than GCA, showing that nonadditive genes predominated in the control of these characteristics (Table 2). Other studies show the predominance of non-additive effects in control of $\mathrm{YT}, \mathrm{YC}$ and TSS and according to these studies, the search for superior hybrids is the best breeding strategy to be adopted (Shende et al., 2012; Souza et al., 2012; Saleem et al., 2013). Other studies report non-additive action being involved in the genetic control of some traits in tomato. Amaral Junior et al. (1999) observed that YT in tomato is controlled by the genes with partial dominance whereas TSS is controlled by the overdominant effect. On the other hand Singh et al. (1999) reported that
TSS in industrial tomato is controlled by complete dominance genes.

For MM, GCA was higher than SCA, and additive genes are predominant in its expression (Table 2). Thus, intrapopulational breeding strategies such as selecting plants with higher frequency of alleles which favors the increase of MM seems to be the most recommended strategy. Garg et al. (2008), Pádua et al. (2010) and Saleem et al. (2013) reported that additive gene actions are predominant in the expression of a higher MM corroborating the results of this work. Amaral Junior et al. (1999) reported that a higher MM is controlled by some genes, whose recessive alleles contribute to the increase of this trait.

In relation to GCA estimates, lines
RVT-08 and RVT-05 figured as the parents with the highest estimates for YT, YC and YP traits (Table 3). These lines contributed positively to the superiority of hybrids in which they participated as parents, due to the presence of favorable alleles for improving these traits. The range of estimates of GCA for the traits YT, YC and YP was $9.80 \mathrm{t} / \mathrm{ha}, 8.43 \mathrm{t} / \mathrm{ha}$ and $1.87 \mathrm{t} /$ ha respectively, corresponding to an average of $17 \%$ of $\mathrm{YT}$ and $\mathrm{YC}$ and $23 \%$ of $\mathrm{YP}$, highlighting the possibility of satisfactory genetic gain only with the choice of suitable parents.

In the current literature, aptitude for combination studies in tomato genotypes in relation to YP was not found. However, in this study, the authors observed that non-additive 
Table 3. Estimates of general aptitude for combination (GCA) for agronomic and post-harvest characteristics, referring to industrial tomato lines, used as genitors in a complete diallel \{estimativas de capacidade geral de combinação (GCA) para características agronômicas e de pós-colheita, referente a linhagens de tomateiro industrial, utilizadas como genitoras em um dialelo completo\}. Guarapuava, UNICENTRO, 2012.

\begin{tabular}{|c|c|c|c|c|c|}
\hline \multirow{2}{*}{$\begin{array}{l}\text { Inbred } \\
\text { lines }\end{array}$} & YT & YC & YP & \multirow{2}{*}{$\begin{array}{c}\text { MM } \\
\text { (g/fruit) }\end{array}$} & \multirow{2}{*}{$\begin{array}{c}\text { TSS } \\
\left({ }^{\circ} \text { Brix }\right)\end{array}$} \\
\hline & & (t/ha) & & & \\
\hline RVT-01 & -4.78 & -4.80 & -0.84 & 9.20 & -0.070 \\
\hline RVT-02 & -1.35 & -0.55 & -0.93 & -4.47 & 0.025 \\
\hline RVT-03 & 0.67 & -0.49 & 0.18 & 3.20 & 0.021 \\
\hline RVT-04 & -2.89 & -1.90 & -0.62 & 0.74 & -0.130 \\
\hline RVT-05 & 3.85 & 3.63 & 0.66 & -3.70 & 0.020 \\
\hline RVT-06 & -2.43 & -1.79 & -0.45 & 5.88 & -0.073 \\
\hline RVT-07 & 1.33 & 1.89 & 0.02 & -1.18 & -0.128 \\
\hline RVT-08 & 5.02 & 2.89 & 0.94 & -1.61 & 0.232 \\
\hline RVT-09 & -0.18 & -0.63 & -0.17 & -9.93 & -0.030 \\
\hline RVT-10 & 0.76 & 0.77 & 0.38 & 1.85 & 0.131 \\
\hline $\mathrm{SD}\left(\hat{\mathrm{g}}_{\mathrm{i}}\right)$ & 0.76 & 0.77 & 0.11 & 0.96 & 0.016 \\
\hline $\operatorname{SD}\left(\hat{g}_{j}-\hat{g}_{\mathrm{I}}\right)$ & 1.13 & 1.14 & 0.16 & 1.43 & 0.024 \\
\hline
\end{tabular}

genes are predominant in control of fruit production and pulp yield, facilitating the tomato breeding for this trait, since these strategies can be adopted for both traits, the search for productive hybrids with excellent pulp yield being the most recommended strategy.

Line RVT-01 obtained the lowest estimate of GCA for YT, YC and YP (Table 3). This line should be avoided in breeding programs which search for genotypes with high YP, YT and YC, since it reduced genotypic value of these traits in crosses in which it took part as parent (Table 3). However, RVT-01 was the line with the highest GCA for MM highlighting the presence of favorable alleles for improving this trait (Table 3).

For TSS, only line RVT-08 stood out for $\operatorname{GCA}\left(0.232^{\circ}\right.$ Brix $)$, contributing for increasing TSS in hybrids in which this line was parent (Table 3). Line RVT-08 stood out as one of the parents with the highest estimate of GCA for YT, YC, YP and TSS, this being a consequence of the presence of favorable alleles in this genotype, which makes it indispensable in breeding programs which aims to improve these traits.

The ideal hybrid according to breeding is that one which presents concomitantly a high estimate of SCA and that, at least, one of its parents shows high estimate of GCA(Cruz et al.,
2012). Estimates of SCA close to zero show that the hybrid behaved close to the expected considering the GCA of their parents. Usually, effects of SCA do not contribute satisfactorily to autogamous breeding, including tomatoes. However, finding transgressive genotypes, which may be selected for their greater genetic merit due to the accumulation of favorable alleles, may be found in populations obtained from hybrids with high SCA and, at least, one of the parents expressing high GCA (Saleem et al., 2013).

For YT, the best hybrids according to SCA were RVT-08 x RVT-09 and RVT-05 $x$ RVD-10 due to their high SCA (Table 4) and for presenting parents RVT-08 and RVT-05 which obtained the two highest GCA for this trait (Table 3 ). The grouping of means showed formation of five different groups for YT, joining the hybrids RVT- $08 \times$ RVT09 (84.37 t/ha) and RVT-07 x RVT-10 $(80.37 \mathrm{t} / \mathrm{ha})$ as the most productive genotypes of the experiment, differing statistically from other genotypes, including the commercial hybrids Tinto and AP-529 (Table 4). The lowest yield of tomato fruits was observed in lines RVT-01 (35.17 t/ha), RVT-02 (40.13 t/ ha) and RVT-09 (40.35 t/ha), which did not differ statistically (Table 4).

Considering tomato for industrial segment, results for YT have been ranged from $14 \mathrm{t} / \mathrm{ha}$ to $124.31 \mathrm{t} / \mathrm{ha}$, the edaphoclimatic conditions and the genotypic constitution of plants being primarily responsible for this wide range (Aragão et al., 2004; Seleguini et al., 2007; Galvão et al., 2013). Schwarz et al. (2013), studying tomato hybrids in the South Central region of Parana observed that the production ranged from $37.18 \mathrm{t} /$ ha to $112.52 \mathrm{t} /$ ha, corroborating the productivities obtained in this work, which ranged from $35.17 \mathrm{t} / \mathrm{ha}$ (RVT-01) to $84.37 \mathrm{t} / \mathrm{ha}$ (RVT-53) (Table 4). These same authors reported values for YT for hybrids AP529 (42.40 t/ha) and Tinto (68.75 t/ha) quite close to those found in this work for these same hybrids (Table 4).

$\mathrm{YC}$ is a very important trait for tomato cultivars for dual purpose market, in which the fruits are intended both for fresh consumption and for industrial processing, depending on price and market fluctuations (Schwarz et al., 2013). The best hybrids for YC according to SCA were: RVT-07 x RVT10, RVT-05 x RVT-06 and RVT-08 x RVT-09 since they showed the highest estimates of SCA of the experiment and concomitantly at least one of their parents (RVT-05, RVT-08 and RVT-07) were good general combiners (Table 3 ). With respect to yield, the best genotypes were RVT-07 x RVT-10 (77.05 t/ha) and RVT-02 x RVT-03 (70.65 t/ha) being the most recommended hybrids for decumbent (not tutored) tomato crop aiming to dual purpose fruit production (Table 3).

The success of an industrial tomato hybrid is directly related to fruit YP, being one of the main traits to be observed when choosing a cultivar (Giordano et al., 2000). Thus, based on estimates of SCA, the best hybrids for YP were RVT-01 x RVT-05 and RVT$08 \times$ RVT-09 (Table 4), as they showed concomitantly positive estimates for SCA and at least one of the parents (RVT-08 and RVT-05) were considered good combiners according to GCA observed (Table 3). With respect to YP, formation of five groups with similar yield was observed. Hybrid RVT-07 x RVT-10 presented the highest YP of the experiment, $12.66 \mathrm{t} / \mathrm{ha}$ being grouped 
Table 4. Specific aptitude for combination (SCA) and average values of 57 genotypes (10 lines, 45 experimental hybrids and 2 commercial hybrids) of tomato for industrial segment considering agronomic and post harvest traits \{capacidade específica de combinação (SCA) e valores médios de 57 genótipos (10 linhagens, 45 híbridos experimentais e 2 híbridos comerciais) de tomateiro com aptidão industrial para características agronômicas e pós colheita\}. Guarapuava, UNICENTRO, 2012.

\begin{tabular}{|c|c|c|c|c|c|c|c|c|c|c|}
\hline \multirow{2}{*}{ Genotype } & \multicolumn{2}{|c|}{ YT(t/ha) } & \multicolumn{2}{|c|}{ YC (t/ha) } & \multicolumn{2}{|c|}{ YP (t/ha) } & \multicolumn{2}{|c|}{ MM (g/fruit) } & \multicolumn{2}{|c|}{ TSS ( ${ }^{\circ}$ Brix) } \\
\hline & Mean & SCA & Mean & SCA & Mean & SCA & Mean & SCA & Mean & SCA \\
\hline RVT-01 & $35.17 \mathrm{f}^{*}$ & - & $29.20 \mathrm{e}$ & - & $4.85 \mathrm{e}$ & - & $80.78 \mathrm{c}$ & - & $4.06 \mathrm{f}$ & - \\
\hline RVT-02 & $40.13 \mathrm{f}$ & - & $37.94 \mathrm{e}$ & - & $5.76 \mathrm{e}$ & - & $56.34 \mathrm{~d}$ & - & $4.25 \mathrm{e}$ & - \\
\hline RVT-03 & $55.82 \mathrm{~d}$ & - & $49.62 \mathrm{~d}$ & - & $7.76 \mathrm{c}$ & - & $74.23 \mathrm{c}$ & - & $4.10 \mathrm{e}$ & - \\
\hline RVT-04 & $38.53 \mathrm{~d}$ & - & $37.57 \mathrm{e}$ & - & $5.36 \mathrm{e}$ & - & $67.96 \mathrm{c}$ & - & $4.11 \mathrm{e}$ & - \\
\hline RVT-05 & $48.43 \mathrm{~d}$ & - & $45.38 \mathrm{~d}$ & - & $6.83 \mathrm{~d}$ & - & $56.71 \mathrm{~d}$ & - & $4.16 \mathrm{e}$ & - \\
\hline RVT-06 & $43.15 \mathrm{~d}$ & - & $38.70 \mathrm{e}$ & - & $5.93 \mathrm{e}$ & - & $74.22 \mathrm{c}$ & - & $4.08 \mathrm{f}$ & - \\
\hline RVT-07 & $60.80 \mathrm{c}$ & - & $54.73 \mathrm{c}$ & - & $7.91 \mathrm{c}$ & - & $57.35 \mathrm{~d}$ & - & $3.85 \mathrm{~g}$ & - \\
\hline RVT-08 & $50.75 \mathrm{~d}$ & - & $45.03 \mathrm{~d}$ & - & $8.02 \mathrm{c}$ & - & $57.54 \mathrm{~d}$ & - & $4.90 \mathrm{a}$ & - \\
\hline RVT-09 & $40.35 \mathrm{f}$ & - & $35.93 \mathrm{e}$ & - & $5.84 \mathrm{e}$ & - & $46.46 \mathrm{~d}$ & - & $4.26 \mathrm{e}$ & - \\
\hline RVT-10 & $43.90 \mathrm{e}$ & - & $38.48 \mathrm{e}$ & - & $6.99 \mathrm{~d}$ & - & $63.14 \mathrm{~d}$ & - & $4.76 \mathrm{a}$ & - \\
\hline $01 \times 02$ & $55.25 \mathrm{~d}$ & 3.31 & $52.83 \mathrm{c}$ & 5.84 & $7.50 \mathrm{c}$ & 0.29 & $77.53 \mathrm{c}$ & 7.10 & $4.03 \mathrm{f}$ & -0.08 \\
\hline $01 \times 03$ & $62.19 \mathrm{c}$ & 8.21 & $49.33 \mathrm{~d}$ & 1.29 & $8.79 \mathrm{c}$ & 1.30 & $88.34 \mathrm{~b}$ & 10.24 & $4.21 \mathrm{e}$ & 0.10 \\
\hline $01 \times 04$ & $45.76 \mathrm{e}$ & -4.63 & $40.52 \mathrm{e}$ & -5.12 & $6.47 \mathrm{~d}$ & -0.21 & $69.75 \mathrm{c}$ & -5.90 & $4.20 \mathrm{e}$ & 0.23 \\
\hline $01 \times 05$ & $71.86 \mathrm{~b}$ & 14.71 & $63.93 \mathrm{~b}$ & 12.75 & $11.54 \mathrm{a}$ & 3.57 & $65.72 \mathrm{~d}$ & -5.46 & $4.71 \mathrm{~b}$ & 0.61 \\
\hline $01 \times 06$ & $56.80 \mathrm{c}$ & 5.94 & $51.05 \mathrm{c}$ & 5.30 & $7.58 \mathrm{c}$ & 0.72 & $88.10 \mathrm{~b}$ & 7.30 & $3.95 \mathrm{f}$ & -0.06 \\
\hline $01 \times 07$ & $55.03 \mathrm{~d}$ & 0.40 & $50.23 \mathrm{~d}$ & 0.79 & $7.03 \mathrm{~d}$ & -0.29 & $77.30 \mathrm{c}$ & 3.57 & $3.76 \mathrm{~g}$ & -0.19 \\
\hline $01 \times 08$ & $60.80 \mathrm{c}$ & 2.48 & $53.58 \mathrm{c}$ & 3.14 & $7.79 \mathrm{c}$ & -1.25 & $75.00 \mathrm{c}$ & 1.70 & $3.86 \mathrm{~g}$ & -0.45 \\
\hline $01 \times 09$ & $52.47 \mathrm{~d}$ & -0.63 & $51.50 \mathrm{c}$ & 4.59 & $7.00 \mathrm{~d}$ & -0.12 & $59.94 \mathrm{~d}$ & -5.02 & $3.96 \mathrm{f}$ & -0.91 \\
\hline $01 \times 10$ & $50.92 \mathrm{~d}$ & -3.13 & $46.77 \mathrm{~d}$ & -1.54 & $6.91 \mathrm{~d}$ & -0.78 & $69.94 \mathrm{c}$ & -6.86 & $4.08 \mathrm{f}$ & -0.14 \\
\hline $02 \times 03$ & $77.11 \mathrm{~b}$ & 19.70 & $70.65 \mathrm{a}$ & 18.37 & $11.77 \mathrm{a}$ & 3.53 & $60.68 \mathrm{~d}$ & -3.73 & $4.50 \mathrm{c}$ & 0.29 \\
\hline $02 \times 04$ & $59.73 \mathrm{c}$ & 5.90 & $55.64 \mathrm{c}$ & 5.75 & $7.49 \mathrm{c}$ & 0.06 & $60.40 \mathrm{~d}$ & -1.56 & $3.70 \mathrm{~g}$ & -0.35 \\
\hline $02 \times 05$ & $56.65 \mathrm{c}$ & 2.30 & $52.61 \mathrm{c}$ & -2.81 & $7.25 \mathrm{c}$ & -1.46 & $54.19 \mathrm{~d}$ & -3.32 & $3.57 \mathrm{~h}$ & -0.62 \\
\hline $02 \times 06$ & $56.60 \mathrm{c}$ & -3.29 & $52.34 \mathrm{c}$ & 2.35 & $8.32 \mathrm{c}$ & 0.72 & $60.61 \mathrm{~d}$ & -6.49 & $4.38 \mathrm{~d}$ & 0.26 \\
\hline $02 \times 07$ & $52.36 \mathrm{~d}$ & -5.70 & $47.26 \mathrm{~d}$ & -6.42 & $8.34 \mathrm{c}$ & 0.27 & $55.20 \mathrm{~d}$ & -4.83 & $4.70 \mathrm{~b}$ & 0.64 \\
\hline $02 \times 08$ & $61.14 \mathrm{c}$ & -0.60 & $54.52 \mathrm{c}$ & -0.15 & $9.89 \mathrm{~b}$ & 0.88 & $62.79 \mathrm{~d}$ & 3.18 & $4.80 \mathrm{a}$ & 0.38 \\
\hline $02 \times 09$ & $62.73 \mathrm{c}$ & 6.18 & $53.07 \mathrm{c}$ & 1.91 & $8.29 \mathrm{c}$ & 0.41 & $59.92 \mathrm{~d}$ & 8.63 & $3.95 \mathrm{f}$ & -0.20 \\
\hline $02 \times 10$ & $60.79 c$ & 3.29 & $54.30 \mathrm{c}$ & 1.73 & $8.10 \mathrm{c}$ & -0.33 & $64.95 \mathrm{~d}$ & 1.83 & $3.93 \mathrm{f}$ & -0.38 \\
\hline $03 \times 04$ & $57.73 \mathrm{c}$ & 1.87 & $53.33 \mathrm{c}$ & 2.39 & $7.51 \mathrm{c}$ & -0.19 & $67.68 \mathrm{c}$ & -1.95 & $3.83 \mathrm{~g}$ & -0.22 \\
\hline $03 \times 05$ & $61.87 \mathrm{c}$ & -0.73 & $55.83 \mathrm{c}$ & -0.65 & $8.39 \mathrm{c}$ & -0.59 & $59.88 \mathrm{~d}$ & -5.29 & $4.16 \mathrm{e}$ & -0.03 \\
\hline $03 \times 06$ & $53.10 \mathrm{~d}$ & -3.21 & $47.75 \mathrm{~d}$ & -3.29 & $6.96 \mathrm{~d}$ & -0.90 & $72.49 \mathrm{c}$ & -2.28 & $3.86 \mathrm{~g}$ & -0.23 \\
\hline $03 \times 07$ & $46.03 \mathrm{e}$ & -14.0 & $42.82 \mathrm{~d}$ & -11.9 & $6.03 \mathrm{e}$ & -2.30 & $71.77 \mathrm{c}$ & 4.07 & $3.86 \mathrm{~g}$ & -0.18 \\
\hline $03 \times 08$ & $65.97 \mathrm{c}$ & 2.19 & $59.72 \mathrm{c}$ & -3.98 & $10.37 \mathrm{~b}$ & 1.09 & $66.56 \mathrm{~d}$ & -0.71 & $4.63 \mathrm{~b}$ & 0.21 \\
\hline $03 \times 09$ & $50.75 \mathrm{~d}$ & -7.89 & $46.14 \mathrm{~d}$ & -6.05 & $7.79 \mathrm{c}$ & -0.36 & $57.73 \mathrm{~d}$ & -1.22 & $4.53 \mathrm{c}$ & 0.37 \\
\hline $03 \times 10$ & $60.58 \mathrm{c}$ & 1.06 & $56.91 \mathrm{c}$ & 3.30 & $8.63 \mathrm{c}$ & -0.08 & $67.38 \mathrm{c}$ & -3.40 & $4.20 \mathrm{e}$ & -0.11 \\
\hline $04 \times 05$ & $59.91 \mathrm{c}$ & 0.88 & $54.76 \mathrm{c}$ & 0.67 & $8.39 \mathrm{c}$ & 0.20 & $68.92 \mathrm{c}$ & 6.18 & $4.13 \mathrm{e}$ & 0.07 \\
\hline $04 \times 06$ & $51.68 \mathrm{~d}$ & -1.07 & $48.81 \mathrm{~d}$ & 0.15 & $7.54 \mathrm{c}$ & 0.47 & $69.21 \mathrm{c}$ & -3.12 & $4.30 \mathrm{~d}$ & 0.34 \\
\hline $04 \times 07$ & $56.32 \mathrm{c}$ & -0.19 & $50.53 \mathrm{~d}$ & -1.80 & $6.37 \mathrm{~d}$ & -1.17 & $59.81 \mathrm{~d}$ & -5.44 & $3.33 \mathrm{i}$ & -0.57 \\
\hline $04 \times 08$ & $70.76 \mathrm{~b}$ & 10.55 & $61.69 \mathrm{~b}$ & 8.35 & $9.36 \mathrm{~b}$ & 0.88 & $63.01 \mathrm{~d}$ & -1.80 & $3.90 \mathrm{~g}$ & -0.36 \\
\hline $04 \times 09$ & $58.47 \mathrm{c}$ & 3.47 & $52.14 \mathrm{c}$ & 2.33 & $8.07 \mathrm{c}$ & 0.71 & $59.58 \mathrm{~d}$ & 3.07 & $4.06 \mathrm{f}$ & 0.07 \\
\hline $04 \times 10$ & $66.65 \mathrm{c}$ & 10.70 & $60.42 \mathrm{c}$ & 9.19 & $10.19 b$ & 2.28 & $77.36 \mathrm{c}$ & 9.02 & $4.50 \mathrm{c}$ & 0.33 \\
\hline $05 \times 06$ & $73.46 \mathrm{~b}$ & 13.96 & $68.23 \mathrm{~b}$ & 14.03 & $10.00 \mathrm{~b}$ & 1.69 & $71.93 \mathrm{c}$ & 4.06 & $4.03 \mathrm{f}$ & -0.07 \\
\hline $05 \times 07$ & $66.00 \mathrm{c}$ & 2.73 & $59.11 \mathrm{c}$ & 1.22 & $10.00 \mathrm{~b}$ & 1.17 & $61.86 \mathrm{~d}$ & 1.06 & $4.46 \mathrm{c}$ & 0.41 \\
\hline $05 \times 08$ & $76.40 \mathrm{~b}$ & 9.08 & $63.14 \mathrm{~b}$ & 4.22 & $11.09 \mathrm{a}$ & 1.33 & $65.46 \mathrm{~d}$ & 5.08 & $4.30 \mathrm{~d}$ & -0.11 \\
\hline $05 \times 09$ & $60.71 \mathrm{c}$ & -1.03 & $56.30 \mathrm{c}$ & 0.95 & $8.25 \mathrm{c}$ & -0.38 & $48.21 \mathrm{~d}$ & -3.84 & $4.00 \mathrm{f}$ & -0.15 \\
\hline $05 \times 10$ & $61.73 \mathrm{c}$ & -0.96 & $54.79 \mathrm{c}$ & -1.97 & $8.93 \mathrm{~b}$ & -0.26 & $68.56 \mathrm{c}$ & 4.67 & $4.26 \mathrm{e}$ & -0.04 \\
\hline $06 \times 07$ & $64.62 \mathrm{c}$ & 7.63 & $58.60 \mathrm{c}$ & 6.14 & $8.68 \mathrm{c}$ & 0.97 & $80.91 \mathrm{c}$ & 10.50 & $3.96 \mathrm{f}$ & 0.01 \\
\hline $06 \times 08$ & $61.02 \mathrm{c}$ & 0.345 & $56.47 \mathrm{c}$ & 3.02 & $9.52 \mathrm{~b}$ & 0.88 & $71.27 \mathrm{c}$ & 1.30 & $4.60 \mathrm{~b}$ & 0.28 \\
\hline $06 \times 09$ & $58.57 \mathrm{c}$ & 3.08 & $52.44 \mathrm{c}$ & 2.52 & $7.34 \mathrm{c}$ & -0.17 & $55.75 \mathrm{~d}$ & -5.89 & $3.70 \mathrm{~g}$ & -0.35 \\
\hline $06 \times 10$ & $47.03 \mathrm{e}$ & -9.38 & $41.18 \mathrm{e}$ & -10.1 & $6.27 \mathrm{~d}$ & -1.80 & $74.58 \mathrm{c}$ & 1.11 & $3.93 \mathrm{f}$ & -0.28 \\
\hline $07 \times 08$ & $50.92 \mathrm{~d}$ & -13.5 & $45.85 \mathrm{~d}$ & -11.2 & $6.80 \mathrm{~d}$ & -2.31 & $62.80 \mathrm{~d}$ & -0.09 & $3.93 \mathrm{f}$ & -0.33 \\
\hline $07 \times 09$ & $62.00 \mathrm{c}$ & 2.77 & $57.66 \mathrm{c}$ & 4.05 & $8.06 \mathrm{c}$ & 0.07 & $56.90 \mathrm{~d}$ & 2.33 & $3.83 \mathrm{~g}$ & -0.17 \\
\hline $07 \times 10$ & $80.37 \mathrm{a}$ & 19.84 & $77.05 \mathrm{a}$ & 22.03 & $12.66 \mathrm{a}$ & 4.13 & $67.19 \mathrm{c}$ & 0.77 & $4.66 \mathrm{~b}$ & 0.50 \\
\hline $08 \times 09$ & $84.37 \mathrm{a}$ & 21.44 & $67.91 \mathrm{~b}$ & 13.30 & $11.74 \mathrm{a}$ & 2.81 & $52.31 \mathrm{~d}$ & -1.82 & $4.65 \mathrm{~b}$ & 0.28 \\
\hline $08 \times 10$ & $66.64 \mathrm{c}$ & 2.77 & $57.57 \mathrm{c}$ & 1.56 & $9.19 \mathrm{~b}$ & -0.28 & $68.98 \mathrm{c}$ & 3.00 & $4.06 \mathrm{f}$ & -0.45 \\
\hline $09 \times 10$ & $65.90 \mathrm{c}$ & 7.24 & $59.14 \mathrm{c}$ & 6.65 & $9.31 \mathrm{~b}$ & 0.95 & $60.15 \mathrm{~d}$ & 2.49 & $4.16 \mathrm{e}$ & -0.09 \\
\hline AP-529 & $44.37 \mathrm{e}$ & - & $40.31 \mathrm{e}$ & - & $6.17 \mathrm{e}$ & - & $56.24 \mathrm{~d}$ & - & $4.10 \mathrm{e}$ & - \\
\hline Tinto & $59.55 \mathrm{c}$ & - & $47.90 \mathrm{~d}$ & - & $7.54 \mathrm{c}$ & - & $104.4 \mathrm{a}$ & - & $3.46 \mathrm{~h}$ & - \\
\hline $\mathrm{SD} \mathrm{S}_{\mathrm{ij}}$ & \multicolumn{2}{|c|}{2.25} & \multicolumn{2}{|c|}{2.32} & \multicolumn{2}{|c|}{0.37} & \multicolumn{2}{|c|}{3.24} & \multicolumn{2}{|c|}{0.053} \\
\hline$S D S_{i j}^{i j}-S_{i k}$ & \multicolumn{2}{|c|}{3.22} & \multicolumn{2}{|c|}{3.80} & 0. & & & & & \\
\hline $\mathrm{SD} \mathrm{S}_{\mathrm{ij}}^{\mathrm{ij}}-\mathrm{S}_{\mathrm{kl}}$ & 3.6 & & 3. & & 0. & & 4. & & & \\
\hline
\end{tabular}

${ }^{*}$ Means followed by the same letter belong to the same group, according to Scott Knott group ( $\left.<<0,05\right)$ \{médias seguidas pela mesma letra pertencem ao mesmo grupo, de acordo com teste de agrupamento $\operatorname{Scott} \operatorname{Knott}(\mathrm{p}<0,05)\}$. 
with other hybrids RVT-02 x RVT-03, RVT-08 x RVT-09, RVT-01 x RVT-05 and RVT-05 x RVT-08 (Table 4).

For MM, the hybrids which showed the highest estimates of SCA and concomitantly at least one of the parents with good estimate of GCA were: RVT01 x RVT-03, RVT-01 x RVT-06 and RVT-01 x RVT-02 (Table 4). All the hybrids previously mentioned showed in common the parent RVT-01 due to being the same line with the highest GCA for MM of the diallel (Table 3). For this experiment, no experimental hybrid exceeded the check hybrid Tinto, which presented the highest MM of the experiment (104.40 g/fruit) not being grouped with any other genotype (Table 4).

TSS influences directly the flavor and the yield of tomato pulp; and the price paid for the raw material is directly related to TSS (Giordano et al., 2000). According to SCA, the best industrial tomato hybrids considering TSS were: RVT-02 x RVT-08, RVT-03 x RVT-08, RVT-06 x RVT-08 and RVT08 x RVT-09 due to presenting high estimates of SCA and concomitantly the parent RVT-08, as it also showed high estimate of GCA (Table 3 ). The means grouping test joined genotypes in nine different groups (Table 4). Line RVT-08 showed the highest value for TSS in the experiment (4.90) being grouped with the hybrid RVT-02 X RVT-08 (4.80 ${ }^{\circ}$ Brix) and the line RVT-10 (4.76 ${ }^{\circ}$ Brix) (Table 4$)$.

This way, the authors concluded that diallel crosses have led to the formation of superior experimental hybrids, in comparison to the checks used in the experiment, the following simple hybrids being highlighted RVT08 x RVT-09, RVT-07 x RVT-10 and RVT-08 x RVT-10 which exceeded the commercial hybrids in relation to fruit productivity and pulp yield. Regarding the control of gene expression, the authors concluded that non-additive genes predominated for controlling YT, YC, YP and TSS traits, whereas additive genes predominated for MM. Parents RVT-08, RVT-05 and RVT-10 are the most appropriate for intrapopulational breeding.

\section{ACKNOWLEDGEMENT}

CAPEs for financial support, FINEP, NUPH and UNICENTRO.

\section{REFERENCES}

AKHTAR S; HAZRA P. 2013. Nature of gene action for fruit quality characters of tomato (Solanum lycopersicum). African Journal of Biotechnology 12: 2869-2875.

AMARAL JÚNIOR AT; CASALI VW; CRUZ CD; FINGER FL. 1999. Inferências genéticas na produção e qualidade do tomateiro sob cruzamento dialélico. Pesquisa Agropecuária Brasileira 34: 1407-1416.

AMARAL JÚNIOR AT; CASALI VWD; CRUZ CD; FINGER LF; SCAPIM CA. 1997. Melhoramento do tomateiro: II. Procedimento de Gardner e Eberhart na análise heterótica de características morfoagronômicas e da qualidade dos frutos. Bragantia 56: 33-44.

ANDRADE MC; SILVA AA; CONRADO TV; MALUF WR; ANDRADE TM; OLIVEIRA CD. 2014. Capacidade combinatória de linhagens de tomateiro em híbridos tipo italiano. Bragantia 73: 237-245.

ARAGÃO FAS; GIORDANO LB; MELO PCT; BOITEUX LS. 2004. Desempenho de híbridos experimentais de tomateiro para processamento industrial nas condições edafoclimáticas do cerrado brasileiro. Horticultura Brasileira 22: 529-533.

BOITEUX LS; FONSECA MEN; GIORDANO LB; MELO PCT. 2012. Melhoramento genético. In: CLEMENTE FMVT; BOITEUX LS (eds). Produção de tomate para processamento industrial. Brasília: Embrapa. p.17-27.

BRASIL. 1995. Ministério da Agricultura do Abastecimento e da Reforma Agrária. Portaria $\mathrm{n}^{\circ} 553$ de 30 de agosto de 1995. Diário Oficial da República Federativa do Brasil, Brasília.

CRUZ CD. 2013. GENES - a software package for analysis in experimental statistics and quantitative genetics. Acta Scientiarum, 35: 271-276.

CRUZ CD; REGAZZI AJ; CARNEIRO PCS. 2012. Modelos biométricos aplicados ao melhoramento genético. Viçosa: UFV. 514p.

ELSAYED AY; SILVA DJH; CARNEIRO PCS; MIZUBUTI ESG. 2012. The inheritance of late blight resistance derived from Solanum habrochaites. Crop Breeding and Applied Biotechnology 12: 199-205.

GALVÃO AG; RESENDE JTV; MORALES, RGF; LUSTOSASBC; DIAS DM; MARODIN JC. 2013. Tomato yield and soil chemical attributes depending on previous cover crops. Horticultura Brasileira 31: 68-73.

GAMEIRO AH; CAIXETA FILHO JV; ROCCO CD; RANGEL R. 2007. Estimativa de perdas no suprimento de tomates para processamento industrial no estado de Goiás. Informações Econômicas 37: 07-16.

GARG N; CHEEMA DS; DHATT AS. 2008.
Genetics of yield, quality and shelf life characteristics in tomato under normal and late planting conditions. Euphytica 159: 275-288.

GIORDANO LB; SILVA JBC; BARBOSA V. 2000. Escolha de cultivares e plantio. In: SILVA JBC; GIORDANO LB (eds). Tomate para processamento industrial. Brasília: EMBRAPA. p.36-59.

GRIFFING B. 1956. A generalized treatment of the use of diallel crosses in quantitative inheritance. Heredity 10: 31-50.

MACIEL GM; MALUF WR; SILVA VF; GONÇALVES NETO AC; NOGUEIRA DW; GOMES LAA. 2010. Heterose e capacidade de combinação em linhagens de tomateiro ricas em acilaçucares. Ciência e Agrotecnologia 34: 1161-1167.

MALUF WR. 2001. Heterose e emprego de híbridos $\mathrm{F}_{1}$ em hortaliças. In: NASS LL; VALOIS ACC; MELO IS; VALADARES MC (eds). Recursos genéticos e Melhoramento - Plantas. Rondonópolis: Fundação MT. p.327-356.

PÁDUA TRP; GOMES LAA; MALUF WR; CARVALHO FILHO JLS; GONÇALVES NETO AC; ANDRADE MC. 2010. Capacidade combinatória de híbridos de tomateiro de crescimento determinado, resistentes a Begomovirus e Tospovirus. Pesquisa Agropecuária Brasileira 45: 818825.

RESENDE LV; MALUF WR; GOMES LAA; MOTA FMF; RESENDE JTV. 2000. Análise dialélica de firmeza de frutos em cultivares e linhagens de tomateiro (Lycopersicon esculentum Mill). Ciência e Agrotecnologia 23: 8-14.

SALEEM MY; ASGHAR M; IQBAL Q; RAHMAN AU; AKRAM M. 2013. Diallel analysis of yield and some yield components in tomato (Solanum lycopersicum L.). Pakystan Journal of Botany 45: 1247-1250.

SANTOS FFB; RIBEIRO A; SIQUEIRA WJ; MELO AMT. 2011. Desempenho agronômico de híbridos $\mathrm{F}_{1}$ de tomate de mesa. Horticultura Brasileira 29: 304-310.

SCHWARZ K; RESENDE JTV; PRECZENHAK AP; PAULA JT; FARIA MV; DIAS DM. 2013. Desempenho agronômico e qualidade físicoquímica de híbridos de tomateiro em cultivo rasteiro. Horticultura Brasileira 31: 410-418.

SELEGUINI A; SENO S; FARIA JÚNIOR, MJA. 2007. Híbridos de tomateiro industrial cultivado em ambiente protegido e campo aberto. Cientifica, 35: 80-87.

SHENDE VD; SETH T; MUKHERJEE S; CHATTOPADHYAY A. 2012. Breeding tomato (Solanum lycopersicum L.) for higher productivity and better processing qualities. SABRAO Journal of Breeding and Genetics 44: 302-321.

SINGH S; DHALIWAL MS; CHEEMA DS; BRAR GS. 1999. Diallel analysis of some processing attributes in tomato. Journal of Genetic and Breeding 52: 265-269.

SOUZA LM; PATERNIANI MEAGZ; MELO PCT; MELO AMT. 2012. Diallel cross among fresh market tomato inbreeding lines. Horticultura Brasileira 30: 246-251. 